free and enlightened voter, to submit to taxation in order that another voter might carry on his business.

This brings us to the only other source of revenue, 2 , "the candidate."

When I was requested to prepare this paper there came upon me a sudden elation, for it seemed that for once I knew where to go for the desired information.

In a chat with a lawyer along the lines of dental legislation, he gave me the impression that the state should pay the costs of examination, but alas, when I hastened to him, note-book in hand, I found that I had misunderstood his remarks. Our talk had been of a certain retroactive clause in a proposed dental bill, and that which he had intended to say was, that if this bill should pass it would be a hardship to compel certain ones to pay a second fee, and in justice the state in this case should be responsible.

Continuing the conversation after $I$ had stated the question I was to deal with, the attorney assured me that so far as he was informed of the various licensegranting powers, there could be but one answer to the question. Later investigation has convinced me of the soundness of his opinion.

In the work of various other boards, for example, health. forestry, and fisheries, the expenses justly come from the public funds, as the benefit is not for individuals, but for the people; but in the case of a license to carry on some trade or profession, whereby an individual is allowed certain privileges, the individual should pay the costs, notwithstanding the fact that the laws governing such cases are enacted for public protectiun.

Let us glance for a moment along the various walks in life where licenses are required before one can enter the ranks, and see by actual reference to a few state laws, from what source the revenue is obtained: Georgia, state board of embalmers, license $\$ 5$, from the candidate; Ohio, physicians, dentists and druggists, fee $\$ 25$, from the candidate; South Carolina, homeopathic board, fee $\$ 5$, from the candidate; New Hampshire, plumbers, fee \$1. for examination, 50 cents every year, from the candidate; Virginia, medicine and surgery, fee $\$ 10$, from the candidate; Nebraska, barbers, examination $\$ 1$, and annually $\$ 1$, from the candidate; Michigan, barbers, examination $\$ 5$, and annually 50 cents, from the candidate; barbers in business at passage of law, $\$ 1$, and annually 50 cents, from the candidate; Tennessee, osteopathy, fee from candidate for recording diploma from one named college, $\$ 1$, and all not so recorded, fine $\$ 100$.

This list could be continued indefinitely, and would still have the refrain, "from the candidate."

"Where the successful prosecution of a calling requires a certain amount of technical knowledge and professional skill, and the lack of them in the practitioner will result in material damage to the one who employs him, it is a legitimate exercise of police power to prohibit any one from engaging in the calling who has not previously been examined by the lawfully constituted authority and received a certificate in testimony of his qualification to practice the profession." "It is the common custom in all the towns and cities of the United States to require the payment of a certain sum of money as a license fee, for the privilege of prosecuting one's profession or calling. The license is required indiscriminately of all kinds of occupations, whatever may be their character, whether harmful or innocent, whether the license is required for the protection of the public or not. . . . It is either a license, strictly so-called, imposed in the exercise of the ordinary police power of the state, or it is a tax laid in the exercise of the power of taxation. In many cases it becomes exceedingly important to determine under which power the particular license is imposed. For example, if the license is a tax, the bill must originate in the House of Representatives, according to the almost universal requirements of constitutional law. But if it is a police regulation, the bill providing for it is constitutional in whichever house it was introduced." "It is one of the "ways and means' of defraying current expenses." A license tax has been held to be reasonable when imposed upon vendors of milk, hucksters, pedlars, vendors of cigarrettes, upon attorneys, physicians, bankers, hacks and drays and other vehicles. So likewise may such tax be exacted of keepers of places of amusement, of dealers in second-hand articles, pawnshops, insurance brokers, auctioneers. In short, the state has the power to impose a license fee as a tax or a police license upon every kind of business.

"In the regulation of all such occupations, it is constitutional to require those who apply for a license to pay a reasonable sum to defray the expenses of issuing the license, and what is a reasonable sum must be determined by the facts in the case."

"When a municipal corporation is given the power to license useful trades or occupations, it can not use the license as a tax to raise revenue, nor is it authorized to entirely prohibit the exercise of the trade or occupation by any excessive license fee." ${ }^{\prime 2}$ Mr. Justice Manning says:

"A proper license tax is not a tax at all within the meaning of the Constitution or even within the ordinary signification of the word, tax. . . . The imposition of a license tax is in the nature of the sale of a benefit, or privilege to the party who would not otherwise be entitled to the same. The imposition of an ordinary tax is in the nature of the requisition of a contribution from that which the party taxed already rightfully possesses."

I have examined all state laws concerning dentistry, numerous other laws and legal authorities, and so far I have not succeeded in finding a single case where the costs did not fall upon the applicant, therefore in answer to the query: How shall the revenue for conducting the work of the state boards be obtained? I reply: From the candidate.

\section{REVENUE FOR CONDUCTING THE WORK OF BOARDS OF DENTAL EXAMINERS.*}

$$
\begin{aligned}
& \text { V. E. TURNER, D.D.S. } \\
& \text { RALEIGH, } \boldsymbol{N} \text {. c. }
\end{aligned}
$$

\section{BY TAXATION OF THE PEOPLE.}

Although one of the main objects of examining persons wishing to commence the practice is to secure protection for the people from inferior dental service, and it would seem for such immunity the people should be taxed as they are for any other protection which the law affords. This is doubtless the correct principle, as the members of the state boards are state officers, it would seem most rational that they should be paid as other state officers.

But there would be great difficulty in influencing legislation, as any proposed enactment relating to dental surgery or any branch of medicine, which carried with it a draft upon the treasury of a state, would excite the

1. Tledeman's Police Regulation of Sklled Trades and Professtons.

2. American and Englich Encyclopedia of Law.

* Read in the Section on Stomatology, at the Fifty-Becond Annual Meeting of the American Medical Association, beld at St. Paul, ilinn., June 4-7, 1901. 
opposition of the average legislator. It would not be expedient to ask this, as it would be fatal to any further amendment to our present dental laws. In fact, in some of the states, it is specially provided that under no circumstances shall these dental enactments be of any expense to the state.

\section{BY FEES FROM THE EXAMINATION OF CANDIDATES.}

All things considered, the most satisfactory plan of securing compensation for the service rendered by members of the state examining boards should be derived from the fees received from the applicants for license. All legislation prescribing and controlling the standard of qualifications of licentiates in dental surgery has been effected through the influence of state dental societies, and every one will concede that such enactments are of great benefit not only to the public but to all reputable practitioners in maintaining a higher standard of professional attainments, which gives more dignity and a hicher consideration among the other professions as well as the public.

It is for these reasons, to a great extent, that it is most earnestly desired that the incompetent and unworthy should be excluded from the practice.

The amount of compensation should be to some extent commensurate with a reasonable expectation of income to be derived from these fees. Of course, in some states it would be larger than in others, but a per diem of $\$ 10$ or $\$ 15$ and 3 cents mileage would not be extravagant remuneration for members of examining boards, except the secretary, who should be paid $\$ 25$ per annum additional.

If these and such other legitimate expenses should aggregate less than the amount of fees received, the balance should be turned over to the state society for conducting scientific research or other educational purposes. If these amounts should aggregate more than the fees, then the state society should supply the deficit. It should not be asked of any competent practitioner to attend these meetings and make these examinations for less compensation than the amount mentioned.

In addition to these duties, each member must prepare suitable question lists before the meeting and examine the replies after, in order to give the proper grading to each applicant examined, and both of these require the exercise of much thought and judgment.

\section{BY TAXATION OF THE PROFESSION.}

If this should be necessary, then the profession should not hesitate to bear that burden for the sake of the benefit which is derived from a proper discrimination between the worthy and qualified and the unworthy and incompetent; and in order to prevent the lowering of the standards of professional equipment and to provide against the advent of those who pursue the calling as a hustling business rather than a learned and dignified profession.

Hydrotherapy Without Water or Cold.-Winternitz, the professor of hydrotherapy at Vienna, states that in the local application of alcohol compresses we have an effective hydrotherapy without water and without cold. First introduced by Salzwedel for phlegmonous inflammations of the skin, Winternitz has found them extremely beneficial in herpes zoster, in the gangrenous as well as the hemorrhagic form. The pain vanishes almost immediately after the application of the alcohol, and the process arrested and cured. 'The compress is made of six to eight layers of absorbent gauze dipped in 65 per cent. alcohol, covered air tight and left for twenty-four hours.

\section{THE DENTAL COLLEGE STANDARD.*}

\author{
1. IS IT WHAT IT SHOULD BE? 2. IF NOT, WHAT \\ IMPROVEMENTS SHOULD BE MADE? 3. HOW \\ MAT THE REQUIREMENTS BE IMPROVED? \\ CIIAS. C. CHITTENDEN, D.D.S. \\ MADISON, WIS.
}

In order to intelligently consider the subject in hand it will be well to first define, if possible, what is the dental college educational standard as at present accepted in this country.

Much agitation and discussion of the subject has for the past two or three years occupied the attention of the journals and the various dental societies, from the national bodies down to the smaller local organizations, as to what the standard should be, but the average practitioner would be at a loss to define what the present situation is if asked to do so. The fact is the whole matter is in a state of evolution just now, the general trend and consensus of opinion seeming to be that high school graduation is the probable goal within the next few years. The fact also is that until 1899 there never was any established standard in this country, each school being a law unto itself as to whom it should matriculate and graduate. The National Examiners sought for years to induce National Faculties to establish a minimum standard as a basis from which to go forward, but it was not until an open rupture, based on a standard demanded by the Examiners as a criterion of reputability and recommendation of schools to the various boards, brought the two national bodies together at Niagara Falls in 1899 in a conference which resulted in the following code of rules being placed on the records of the Faculties Association:

"The minimum preliminary educational requirement of colleges of the association. for the session of 18991900 , shall be a certificate of entrance into the second year of a high school, or its equivalent, the preliminary examination to be placed in the hands of any state or county superintendent of public instruction."

Amended Rule VIII. National Association Dental Examiners, Sec. 2.- "The following preliminary examination shall be required of students seeking admission to colleges recommended by this association: The minimum preliminary educational requirements of colleges of this association for the session of 1900-1901 shall be certificate of entrance in the second year of a high school, or its equivalent; the preliminary examination to be placed in the hands of the State Superintendent of Public Instruction, as adopted by the State Board of Missouri."

Also, "the minimum preliminary educational requirement of the colleges of this Association, beginning with the session of the year 1902-1903, shall be a certificate of entrance into the third year of high school, or its equivalent. The preliminary examination to be placed in the hands of the State Superintendent of Public Instruction. Nothing in this rule shall be construed to interfere with colleges of this association that are able to maintain a higher standard of preliminary education."

The above represents the exact situation at this time, to-wit: present standard, one year of high school, promised standard for 1902 , two years of high school, with the agreement between the two bodies that all schools

- Read In tle Section on Stomatology, at the Fifty-second Annual Meeting of the American Medical Association, held at St. Paul, Minn., Jane 4-7, 1901. 